\title{
Hydrologic and Morphometric Analysis of Ofu River Sub-Basin using Remote Sensing and Geographic Information System
}

\author{
M. I. Alfa ${ }^{1 *}$, M. A. Ajibike ${ }^{2}$, D. B. Adie' 2 O. J. Mudiare ${ }^{3}$ \\ ${ }^{1}$ Department of Civil Engineering, University of Jos, Jos, Nigeria. \\ ${ }^{2}$ Department of Water Resources \& Environmental Engineering, Ahmadu Bello University, Zaria, Nigeria. \\ ${ }^{3}$ Department of Agricultural \& Bioresource Engineering, Ahmadu Bello University, Zaria, Nigeria.
}

\begin{abstract}
The morphometric characteristics of a river basin are very important factors in watershed hydrology. The morphometric analysis of the Ofu River sub-basin was carried out in this study to assess its morphologic and hydrological characteristics as well as its flood potentials based on the morphological characteristics. The study was carried out using remotely sensed spatial data analysed using Geographical Information Systems (GIS). The morphometric parameters analysed were the areal, linear, and relief aspects of the sub-basin. The results showed that Ofu river sub-basin covers a total area of $1604.56 \mathrm{~km}^{2}$ and a perimeter of $556.98 \mathrm{~km}$ covering parts of Kogi and Enugu States in Nigeria. The sub-basin has 3rd order river network based on the Strahler's classification with a dendritic drainage pattern and moderate drainage texture. The values of bifurcation ratio, drainage density, circularity ratio, elongation ratio, form factor, stream frequency and drainage intensity indicate that the sub-basin is elongated and would produce a flatter peak of direct runoff for a longer duration implying that the sub-basin is morphometrically less susceptible to flood and that any flood flow that may emanate from it would be easy to manage.
\end{abstract}

KEYWORDS: Delineation, GIS, Morphometric analysis, Ofu river sub-basin, Remote sensing.

\section{INTRODUCTION}

Morphometric analysis of a river basin refers to the measurement and mathematical evaluation of the surface, shape and dimension of its landform (Agarwal, 1998; Obi et al., 2002; Kulkarni, 2015). The morphometric characteristics of a river basin are very important factors in watershed hydrology. They reflect the hydrological behaviour of the river basin and are useful in evaluating the hydrologic response of the basin. There are relationships between river basin morphometric parameters and flood potential. For instance, higher drainage density indicates faster runoff and a more significant degree of channel abrasion for a given quantity of rainfall (Withanage et al., 2014). Rivers and fluvial processes are the most dominant geomorphic systems of earth's surface responsible for morphometric changes in drainage basin or the watershed (Horton, 1945). Sapkale (2013), in buttressing this stated that the geological nature of basin and its landform generally controls the river, influence the channel slope and reveals possibilities of erosion and depositions of the river.

Quantitative morphometric analysis of a river basin facilitates an understanding of the drainage characteristics and development, surface runoff generation, infiltration capacity of the ground as well as groundwater potential (Ibrampurkar, 2012; Raj and Azeez, 2012).

*Corresponding author: meshilalfa@gmail.com
The systematic description of the geometry of a river basin and its stream channel requires the measurement of linear aspects of the drainage network, areal aspects of the drainage basin, and relief or gradient aspects of the channel network and contributing ground slopes (Strahler, 1964; Withanage et al., 2014). Various researchers across the world have carried out morphometric analysis of various river basins in different continents of the world. Waikar and Nilawar (2014) carried out morphometric analysis for the drainage basin in Charthana, located in Parbhani district of Maharashtra state in India, extracting linear, areal and relief aspects of the basin characteristics. The parameters estimated include stream length, bifurcation ratio, drainage density, stream frequency, texture ratio, elongation ratio, circularity ratio and form factor ratio amongst others. Similarly, Raj and Azeez (2012) carried out morphometric analysis for Barathapuzha River in Southern India. GIS and remote sensing tools were used to study the morphometric characteristics of the basin. They also determined the linear, areal and relief aspects of the watershed characteristics. They noted that the Barathapuzha River, the second longest river in the state of Kerala was a seventh order river formed by several lower order streams resulting to a dentritic flow pattern. Similarly, Withanage et al. (2014) carried out morphometric analysis of the Gal Oya River Basin in Sri Lanka to assess its hydrological characteristics and flood potentials based on the morphological characteristics. They doi: http://dx.doi.org/10.4314/njtd.v16i2.1 
utilized spatial data obtained from Geographical Information Systems (GIS) to estimate the linear, areal and relief aspects of the basin characteristics. They noted that the Gal Oya River was a $6^{\text {th }}$ order river network following the Strahler's classification with a dendritic drainage pattern and moderate drainage texture. Martins and Gadiga (2015) also carried out morphometric analysis of upper Yedzaram catchment of Mubi in Adamawa State, Nigeria using Geographic Information System (GIS). The study focused on the hydrological and geometrical analysis with emphasis on the linear and areal morphometric characteristics of the catchment.

Morphometric analysis of Ofu River sub-basin became necessary to form a basis for the detailed assessment of the flood hazard, vulnerability and risk within the catchment. This will also provide a sound basis for the management of the watershed for optimum development of the resources within it. The morphometric analysis of the Ofu River subbasin was carried out in this study to assess its morphologic and hydrological characteristics as well as its flood potentials based on the morphological characteristics.

\section{MATERIALS AND METHODS}

\section{A. The Study Area}

Ofu River sub-basin lies between latitudes $6^{\circ} 46^{\prime} 48.38^{\prime \prime}$ $\mathrm{N}$ and $7^{\circ} 38^{\prime} 31.2^{\prime \prime} \mathrm{N}$ and longitudes $6^{\circ} 42^{\prime} 43.56^{\prime \prime} \mathrm{E}$ and $7^{\circ}$ 20' 54.6' ' E covering parts of Dekina, Ofu, Igalamela/Odolu, Idah and Ibaji Local Government Areas in Kogi State and Uzo-Uwani Local Government Area in Enugu State, Nigeria (Fig. 1), within the humid tropical rain forest of Nigeria. It falls within the Lower Benue River Basin Development Authority in North Central Nigeria. Rainfall within the catchment is concentrated in one season lasting from April/May to September/October. The main river within the sub-basin $(\mathrm{Ofu})$ is perennial and parallel in pattern to Imabolo and Okura rivers which are close to the study area. It took its root from Ojofu, in Dekina Local Government area in Kogi State flowing in the eastward direction with a catchment area amounting to about $1,604 \mathrm{~km}^{2}$ most of which is covered by dense forest. Okura River joined Imabolo River in Egabada (Kogi State) and further flow southwards before joining the Ofu River and the 'three-in-one' river empties into the famous Anambra River in Anambra State (Gideon et al., 2013).

\section{B. Delineation of Ofu River Watershed}

The delineation of Ofu River Catchment was carried out using the Shuttle Radar Topographic Mission Digital Elevation Model (SRTM-DEM) version 3 and the drainage network extracted from the River map of Africa. The preprocessing was done using ArcHydro extension in ArcGIS 10.2.2 while the actual delineation was done using HECGeoHMS extension in ArcGIS 10.2.2 with the DEM and drainage network as input.

\section{Estimation of Morphometric Parameters}

Areal characteristics such as basin area, perimeter, longest flow path and main stream length were extracted from the attribute tables of the sub-basin and the main river in

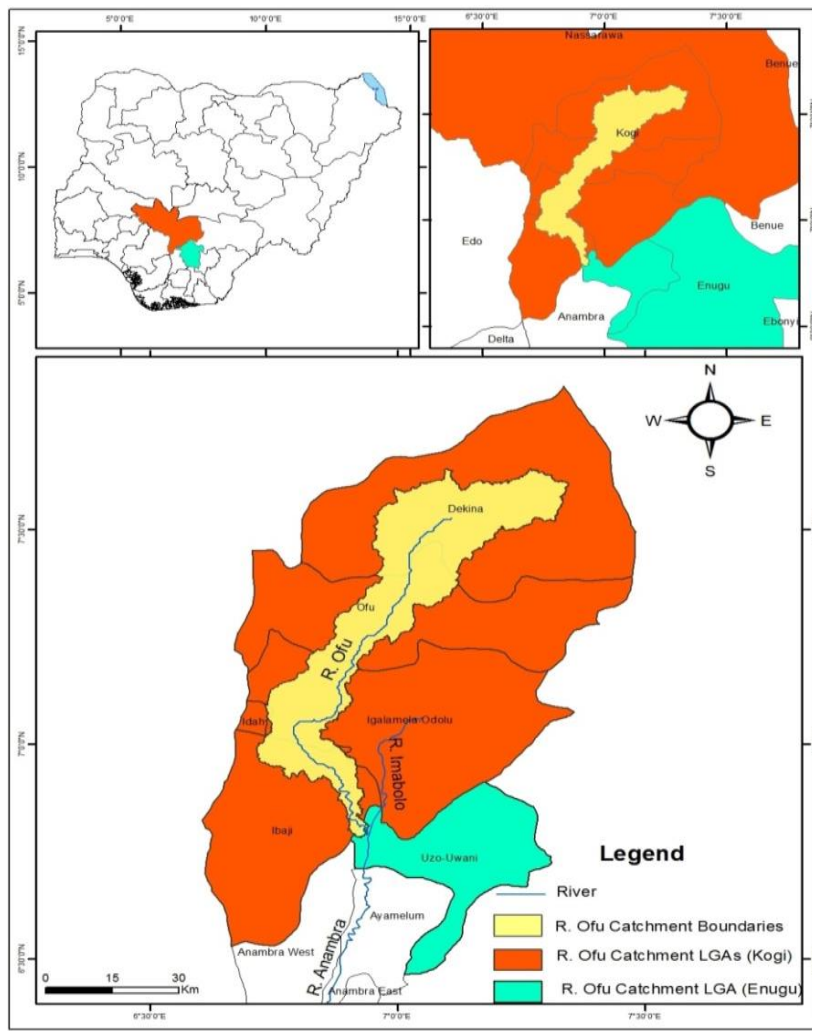

Fig. 1: Map of Study Area Source: Adapted from the Administrative Map of Nigeria, LOC (n.d); www.nationsonline.org

ArcGIS while the other parameters were estimated using the respective equations developed previously as shown in Tables $1-3$.

\section{RESULTS AND DISCUSSION}

The boundaries of Ofu River catchment delineated in this study using remote sensing and GIS is shown in Fig.2. The figure shows the basic areal characteristics of the catchment.

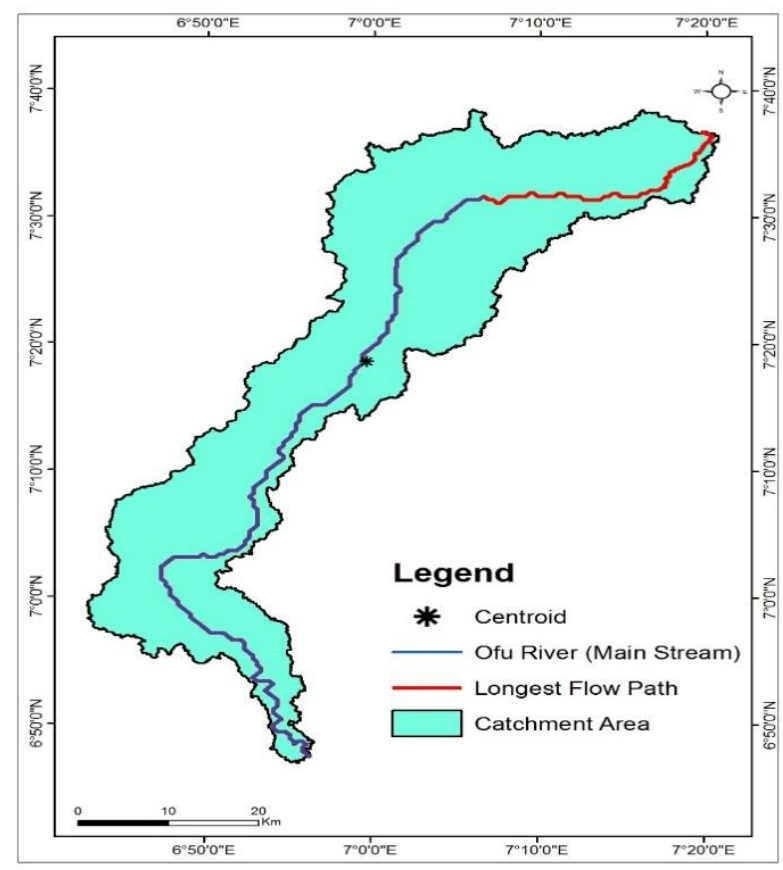

Fig. 2: Areal Characteristics of Ofu River Catchment. 


\begin{tabular}{|c|c|c|c|}
\hline Parameter & Symbol & Formula & Reference \\
\hline Area & A & GIS Analysis & - \\
\hline Perimeter & $\mathrm{P}$ & GIS Analysis & - \\
\hline Basin Length & $\mathrm{L}_{\mathrm{b}}$ & GIS Analysis & Schumm (1956) \\
\hline Longest Flow Path & $\mathrm{L}_{\mathrm{fp}}$ & GIS Analysis & - \\
\hline Main Stream Length & $\mathrm{S}_{\mathrm{L}}^{\mathrm{lp}}$ & GIS Analysis & - \\
\hline Basin Centroid Longest Flow Path & $\mathrm{L}_{\text {cfp }}$ & GIS Analysis & - \\
\hline Elongation ratio & $\mathrm{R}_{\mathrm{e}}$ & $R_{e}=2 \sqrt{ }(A / n) / L_{b}$ & Schumm (1956) \\
\hline Circularity ratio & $\mathrm{R}_{\mathrm{c}}$ & $\left.R_{c}=4 n A\right) / P^{2}$ & Miller (1953) \\
\hline Form factor & $F_{f}$ & $F_{f}=A / L_{b}^{2}$ & Horton (1932) \\
\hline Compactness coefficient & $\mathrm{C}_{\mathrm{c}}$ & $C_{c}=0.282038 P / A^{0.5}$ & Horton (1945) \\
\hline Shape Factor & $\mathrm{B}_{\mathrm{s}}$ & $B_{s}=L_{b}^{2} / A$ & Horton (1932) \\
\hline Stream frequency & $\mathrm{F}$ & $F=\Sigma N_{u} / A$ & Horton (1945) \\
\hline Drainage Density & $D_{d}$ & $D_{d}=\Sigma L / A$ & Horton $(1932 ; 1945)$ \\
\hline Drainage Texture & $\mathrm{D}_{\mathrm{t}}$ & $D_{t}=\Sigma N_{u} / P$ & Horton (1945) \\
\hline Drainage Intensity & $\mathrm{I}_{\mathrm{d}}$ & $I_{d}=F / D_{d}$ & Faniran (1968) \\
\hline Constant of Channel Maintenance & $\mathrm{C}_{\mathrm{m}}$ & $C_{m}=1 / D_{d}$ & Strahler (1952) \\
\hline Length of Overland Flow & $\mathrm{L}_{\mathrm{o}}$ & $L_{o}^{m}=1 / 2 D_{d}$ & Langbein \& Leopold (1964) \\
\hline Channel Sinuosity & $\mathrm{S}_{\mathrm{c}}$ & $S_{c}=\Sigma L_{u} / L_{f p}$ & Le Roux (1992) \\
\hline Time of Concentration & $\mathrm{T}_{\mathrm{c}}$ & $T_{c}=0.000323 L_{f p}{ }^{0.77} S^{-0.385}$ & Kirpich (1940) \\
\hline Time to Recession & $\mathrm{N}$ & $N=0.84 A^{0.2}$ & Mustafa \& Yusuf, 2012 \\
\hline
\end{tabular}

Table 2: Methods used for Estimation of Linear Morphometric Parameters.

\begin{tabular}{lccl}
\hline Parameter & Symbol & Formula & Reference \\
\hline Stream order & $\mathrm{U}$ & GIS Analysis & Strahler (1964) \\
Stream Number & $\mathrm{N}_{\mathrm{u}}$ & GIS Analysis & Horton (1945) \\
Stream Length & $\mathrm{L}_{\mathrm{u}}$ & GIS Analysis & Horton (1945) \\
Mean Stream Length & $\mathrm{N}_{\mathrm{um}}$ & $L_{u m}=L_{u} / N_{u}$ & Strahler (1964) \\
Bifurcation Ratio & $\mathrm{R}_{\mathrm{b}}$ & $R_{b}=N_{u} / N_{u+1}$ & Schumm (1956) \\
Stream Length Ratio & $\mathrm{R}_{\mathrm{L}}$ & $R_{L}=L_{u} / L_{u-1}$ & Horton (1945) \\
\hline
\end{tabular}

Table 3: Methods used for Estimation of Relief Morphometric Parameters.

\begin{tabular}{lcll}
\hline Parameter & Symbol & Formula & Reference \\
\hline Basin Relief & $\mathrm{H}$ & $H=Z-z$ & Strahler (1957) \\
Relief Ratio & $\mathrm{R}_{\mathrm{h}}$ & $R_{h}=H / L b$ & Schumm (1956) \\
Relative Relief & $\mathrm{R}_{\mathrm{hp}}$ & $R_{h p}=H^{*} 100 / P$ & Melton (1957) \\
Ruggedness Number & $\mathrm{R}_{\mathrm{N}}$ & $R_{N}=D_{d} \times(H / 1000)$ & Patton and Baker (1976) \\
Basin Slope & $\mathrm{S}$ & GIS Analysis & \\
\hline
\end{tabular}

\section{A. Areal Characteristics of Ofu River Catchment}

The areal characteristics of the catchment estimated in this study are presented in Table 4 . The results show that Ofu River catchment covers a total area of $1,604.56 \mathrm{~km}^{2}$ and is bounded by a perimeter of $556.98 \mathrm{~km} .41 .89 \%$ of this area falls in Dekina LGA, $24.4 \%$ in Ofu LGA, $19.72 \%$ in Igalamela/Odolu LGA, $0.23 \%$ in Idah LGA and $13.30 \%$ in Ibaji LGA all in Kogi State while $0.42 \%$ falls in Uzo-Uwani LGA in Enugu State.
In addition, the percentage of each LGA land mass drained by Ofu River are 27.02 \%, $23.48 \%, 14.06 \%, 9.25 \%$, $14.04 \%$ and $0.80 \%$ for Dekina, Ofu, Igalamela/Odolu, Idah, Ibaji and Uzo-Uwani LGAs respectively. Schumm's basin length of Ofu River catchment is $100.93 \mathrm{~km}$. the longest flow path is $159.14 \mathrm{~km}$ while the length of main stream (Ofu River) is $121.37 \mathrm{~km}$. The basin's centroid longest flow path is $89.32 \mathrm{~km}$. 
Table 4: Morphometric Characteristics of Ofu River Catchment (Areal Aspects).

\begin{tabular}{|c|c|c|c|}
\hline Parameters & Symbol & Unit & Value \\
\hline \multicolumn{4}{|c|}{ Basic Parameters } \\
\hline Area & A & $\mathrm{km}^{2}$ & 1604.56 \\
\hline Perimeter & $\mathrm{P}$ & $\mathrm{km}$ & 556.98 \\
\hline Basin Length & $\mathrm{L}_{\mathrm{b}}$ & $\mathrm{km}$ & 100.93 \\
\hline Longest Flow Path & $\mathrm{L}_{\mathrm{fp}}$ & $\mathrm{km}$ & 159.14 \\
\hline Main Stream Length & $\mathrm{S}_{\mathrm{L}}$ & $\mathrm{km}$ & 121.37 \\
\hline Basin Centroid Longest Flow Path & $\mathrm{L}_{\mathrm{cfp}}$ & $\mathrm{km}$ & 89.32 \\
\hline \multicolumn{4}{|c|}{ Derived Parameters } \\
\hline Elongation ratio & $\mathrm{R}_{\mathrm{e}}$ & - & 0.45 \\
\hline Circularity ratio & $\mathrm{R}_{\mathrm{c}}$ & - & 0.07 \\
\hline Form factor & $\mathrm{F}_{\mathrm{f}}$ & - & 0.16 \\
\hline Compactness coefficient & $\mathrm{C}_{\mathrm{c}}$ & - & 3.92 \\
\hline Shape Factor & $\mathrm{B}_{\mathrm{s}}$ & - & 6.35 \\
\hline Stream frequency & $\mathrm{F}$ & $\mathrm{km}^{-2}$ & 0.11 \\
\hline Drainage Density & $D_{d}$ & $\mathrm{~km} / \mathrm{Km}^{2}$ & 0.26 \\
\hline Drainage Texture & $\mathrm{T}$ & $\mathrm{km}^{-1}$ & 0.31 \\
\hline Drainage Intensity & $I_{d}$ & $\mathrm{~km}^{-1}$ & 0.42 \\
\hline Constant of Channel Maintenance & $\mathrm{C}_{\mathrm{m}}$ & $\mathrm{km}^{2} / \mathrm{km}$ & 3.90 \\
\hline Length of Overland Flow & $\mathrm{L}_{\mathrm{o}}$ & $\mathrm{km}$ & 1.95 \\
\hline Channel Sinuosity & $\mathrm{S}_{\mathrm{c}}$ & - & 2.59 \\
\hline Time of Concentration & $\mathrm{T}_{\mathrm{c}}$ & Hrs & 6.17 \\
\hline Time from peak to Recession & $\mathrm{N}$ & Days & 3.68 \\
\hline
\end{tabular}

The results further show that the catchment has an elongation ratio of 0.45 , circularity ratio of 0.07 , form factor of 0.16 , compactness coefficient of 3.92 and a shape factor of 6.35. More so, the stream frequency of the catchment is 0.11 $\mathrm{km}^{-1}$ while the drainage density is $0.26 \mathrm{~km} / \mathrm{km}^{2}$. The drainage texture is $0.31 \mathrm{~km}^{-1}$, the drainage intensity $0.42 \mathrm{~km}^{-1}$, while the constant of channel maintenance is $3.90 \mathrm{~km}^{2} / \mathrm{km}$. Finally, the length of overland flow is $1.95 \mathrm{~km}$, and the channel sinuosity is 2.59 while the time of concentration and time from peak to recession were 6.17 hours and 3.68 days respectively implying that while it will take a drop of water 6.17 hours to flow from the remotest part of the catchment to get to the outlet, it will take approximately four days for flood water to recede after peak.

The low value of Drainage density $\left(D_{d}\right)$ of $0.29 \mathrm{~km} / \mathrm{km}^{2}$ indicates that the catchment has highly permeable subsoil and thick vegetative cover. In addition, the low Circularity ratio $\left(\mathrm{R}_{\mathrm{c}}\right)$ of 0.07 obtained also indicates that as the catchment is almost elongated in shape, it has a low discharge rate of runoff and highly permeable subsoil conditions. More so, the low elongation ratio $\left(\mathrm{R}_{\mathrm{e}}\right)$ of 0.45 and Form factor $\left(\mathrm{F}_{\mathrm{f}}\right)$ of 0.16 confirm that the basin is elongated and thus the basin has a flatter peak with a longer duration.
The lower values of Stream frequency $\left(\mathrm{F}_{\mathrm{s}}\right)$ and Drainage intensity $\left(I_{d}\right)$ values further confirm that the surface runoff is not quickly removed from the river basin. The results reveal that the basin is well capable of absorbing water into the soil and recharging groundwater while reducing the risk of flooding. If such floods happen, they could be managed easily from this type of elongated Catchments than from circular basins. The results of the areal morphologic characteristics show that Ofu river catchment is inherently and morphometrically capable of reducing the flood risk but sustainable management plans should be made in advance to cope with the potential floods that can occur due to high rainfalls as has been the case with the low lying flood plains for years.

\section{B. Linear Morphometric Characteristics of Ofu River Catchment}

The analyzed drainage network of the Ofu river catchment is presented in Fig. 3 while the linear aspects of the morphometric analysis conducted for the river network are given in Table 5 .

A total of 39 streams are found in Ofu River catchment. These streams are linked up to the $3^{\text {rd }}$ order spreading over an area of $1,604.56 \mathrm{~km}^{2}$ (Fig. 3). There are a total of 20, 16 and 3 streams of orders 1,2 and 3 , respectively with stream lengths $98.76 \mathrm{~km}, 101.17 \mathrm{~km}$ and $41.47 \mathrm{~km}$ in respective orders. This small number of streams indicates mature topography in the catchment (Zaidi, 2011). The mean stream lengths for order 1, 2 and 3 were, respectively $4.94 \mathrm{~km}, 6.32$ $\mathrm{km}$ and $13.82 \mathrm{~km}$. A plot of the respective logarithm of stream number $\left(\mathrm{N}_{\mathrm{u}}\right)$, stream length $\left(\mathrm{L}_{\mathrm{u}}\right)$ and mean stream length $\left(\mathrm{L}_{\mathrm{um}}\right)$ versus stream order are presented in Figs.4, 5 and 6 .

There was a decrease in stream length (Fig. 5), respectively with increasing order which agrees with Horton (1945). The mean stream length $\left(\mathrm{L}_{u m}\right)$ on the other hand showed an increase with increasing order (Fig. 6) as explained by Strahler (1964). These trends agree with those of previous studies carried out on other similar catchments (Withanage et al., 2014; Waikar et al., 2014).

Dendritic drainage pattern can be observed in Ofu River basin (Fig. 3) which is probably the most common drainage pattern identified in Nigerian river basins and the world at large. This is a randomly developed, tree-like pattern composed of branching tributaries and a main stream, characteristic of essentially flat-lying and/or relatively homogeneous rocks and impervious soils (Zernitz, 1932).

\begin{tabular}{cccccc}
\multicolumn{2}{l}{ Table 5: Morphologic Characteristics of Ofu River Catchment (Linear Aspects) } \\
\hline $\begin{array}{c}\text { Stream Order } \\
(\mathbf{U})\end{array}$ & $\begin{array}{c}\text { Stream } \\
\text { Number }\left(\mathbf{N}_{\mathbf{u}}\right)\end{array}$ & $\begin{array}{c}\text { Stream Length } \\
\left(\mathbf{L}_{\mathbf{u}}\right)\end{array}$ & $\begin{array}{c}\text { Mean Stream Length } \\
\left(\mathbf{L}_{\mathbf{u m}}\right)\end{array}$ & $\begin{array}{c}\text { Bifurcation Ratio } \\
\left(\mathbf{R}_{\mathbf{b}}\right)\end{array}$ & $\begin{array}{c}\text { Stream Length Ratio } \\
\left(\mathbf{R}_{\mathbf{L}}\right)\end{array}$ \\
\hline 1 & 20 & 98.76 & 4.94 & 1.25 \\
2 & 16 & 101.17 & 6.32 & 5.33 & 1.02 \\
3 & 3 & 41.47 & 13.82 & 0.41 & $\mathbf{A v} . \mathbf{R}_{\mathbf{b}}=\mathbf{3 . 2 9}$ \\
\hline
\end{tabular}


This pattern develops on rocks of uniform resistance which indicate a complete lack of structural control (Withanage et al., 2014). It is more likely to be found on nearly horizontal sedimentary rocks or on areas of massive igneous rocks and sometimes on complex metamorphosed rocks (Garde, 2006). Ofu River shares similar geological characteristics with Ankpa which according to Imasuen et al. (2011) falls within

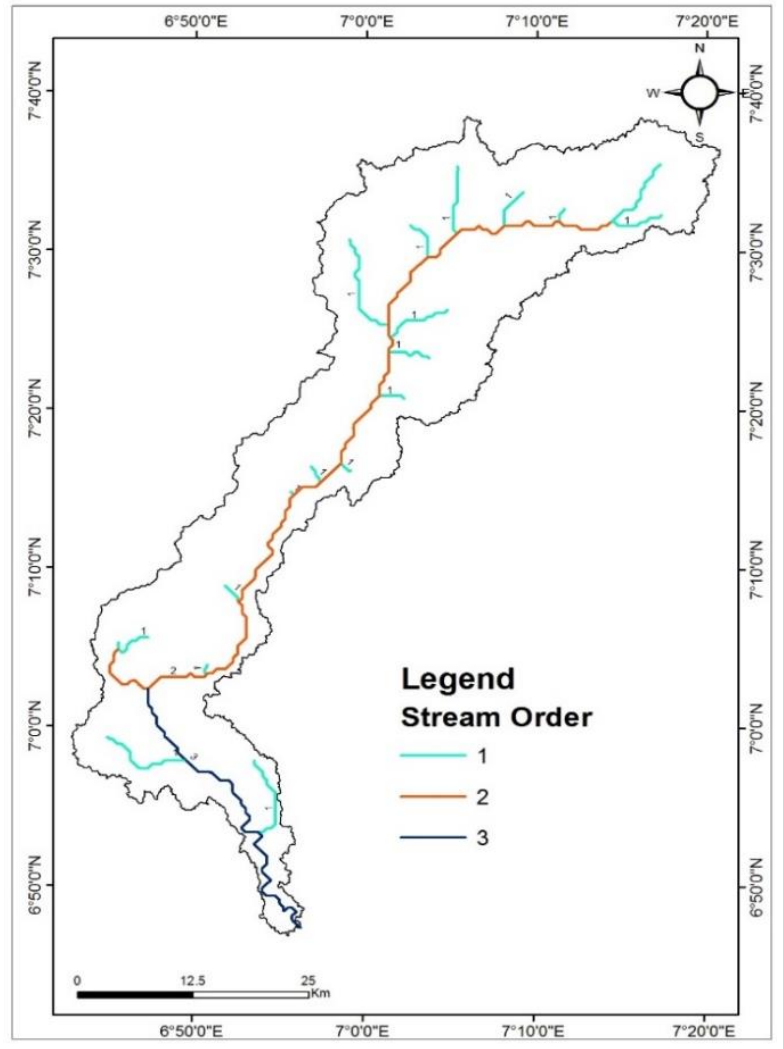

Fig. 3: Strahler's Stream Order of Ofu River Basin.

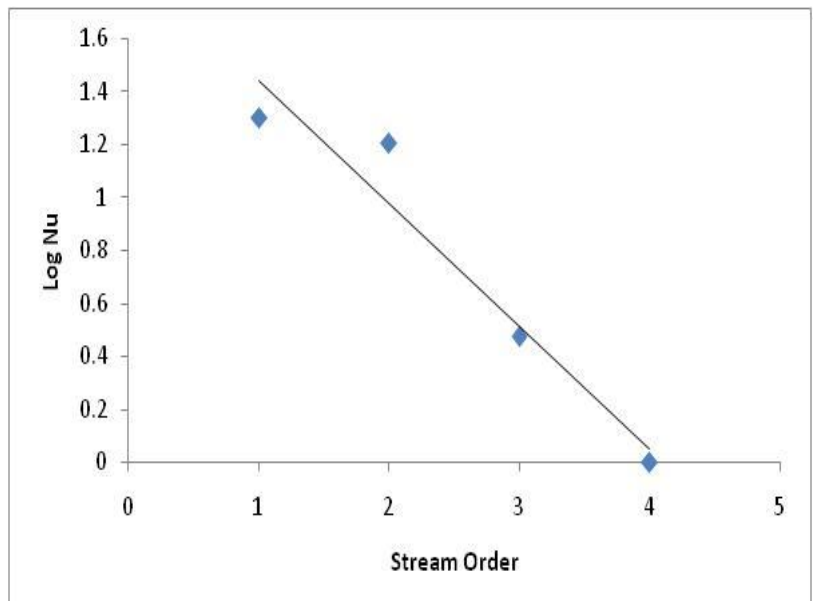

Fig. 4: Logarithm of Stream Number $\left(\mathrm{N}_{\mathrm{u}}\right)$ versus Stream Order $(\mathrm{U})$.

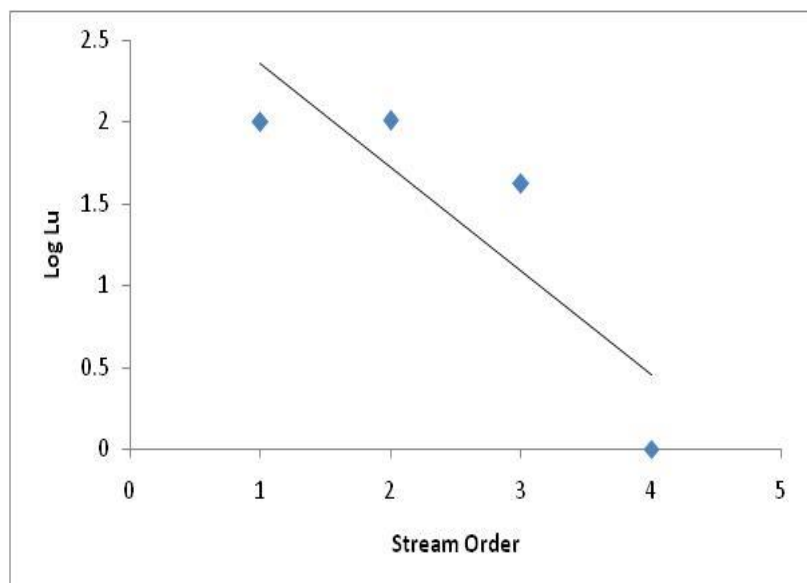

Fig.5: Logarithm of Stream Length $\left(L_{u}\right)$ versus Stream Order $(U)$.

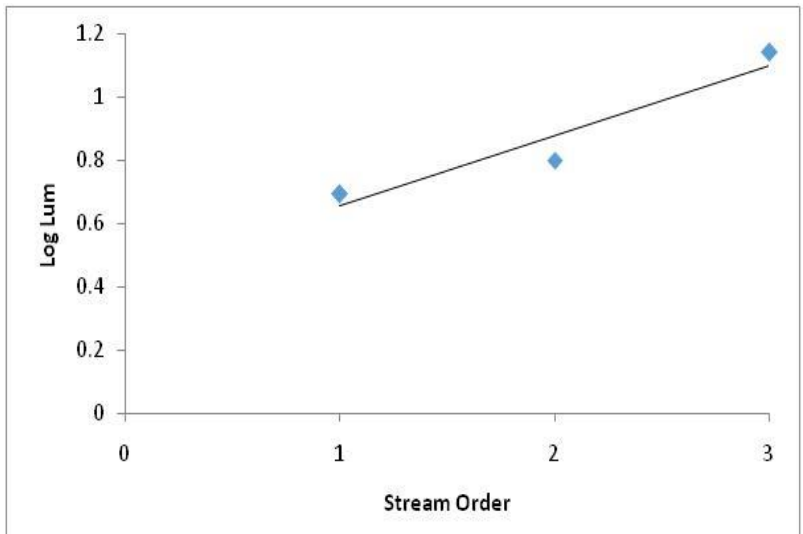

Fig. 6: Logarithm of Mean Stream Length $\left(L_{u m}\right)$ versus Stream Order (U).

the Anambra Basin whose genesis has been linked with the development of the Niger Delta Miogeosyncline and the opening of the Benue Trough. According to them, the Benue Trough is underlain by the rocks of Anambra Sedimentary Basin consisting of the Ajali and Mamu formations.

Furthermore, the bifurcation ratios were 1.25 and 5.33 while the average bifurcation ratio was 3.29. According to Horton (1945), bifurcation ratio is an index of reliefs and dissections. The bifurcation ratios were not the same from one order to the next which according to Strahler, (1964) and Withanage et al. (2014) is attributable to the geological and lithological development of the drainage basin. Strahler (1964) and Nag (1998) stated that lower values of bifurcation ratios are characteristics of watersheds which have suffered less structural disturbances. The higher bifurcation ratio of 5.33 obtained for order 2 streams in this present study indicates that strong structural disturbances have occurred in the basin when the underlying geological structure underwent transformations.

In addition to the forgoing, Chorley et al. (1957) noted that bifurcation ratio could be an index of flood risk level. He 
stated that the lower the bifurcation ratio, the higher the risk of flooding, particularly of parts and not the entire basin. This explains why the flooding within the Ofu River catchments affects only a part of the basin amongst other factors. The

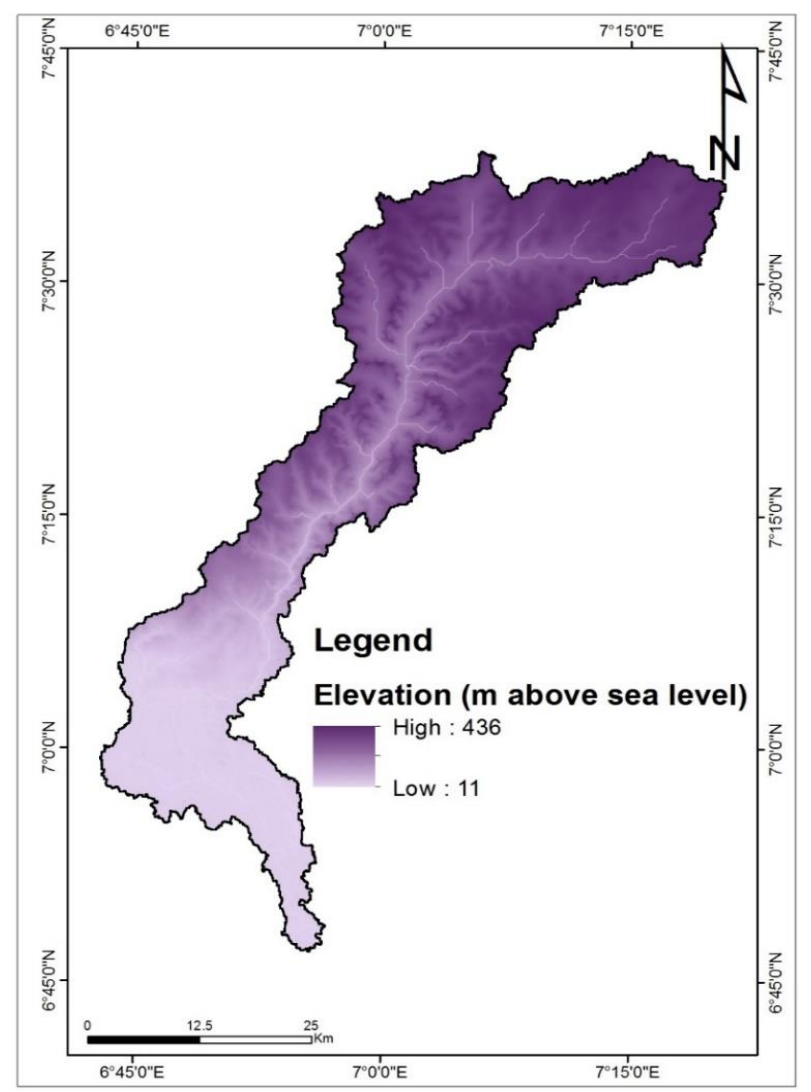

Fig. 7: Digital Elevation Model (DEM) of Ofu River Catchment.

values of bifurcation ratio $\left(\mathrm{R}_{\mathrm{b}}\right)$ obtained in this study $(1.25$ and 5.33), the high average of 3.29 together with the elongated shape of Ofu River basin would result in a lower and extended peak flow, which will reduce the risk of flooding within the basin.

\section{Relief Morphologic Characteristics of Ofu River Catchment}

The Digital Elevation Model (DEM) of Ofu River catchment is shown in Fig.7 while the relief characteristics of the catchment are presented in Table 6.

Table 6: Morphologic Characteristics of Ofu River Catchment (Relief Aspects).

\begin{tabular}{llll}
\hline Parameters & Symbol & Unit & Value \\
\hline Highest Elevation & $\mathrm{Z}$ & $\mathrm{m}$ asl. & 436 \\
Lowest Elevation & $\mathrm{Z}$ & $\mathrm{m}$ asl. & 11 \\
Basin Relief & $\mathrm{H}$ & $\mathrm{m}$. & 425 \\
Relief Ratio & $\mathrm{R}_{\mathrm{h}}$ & - & 0.0042 \\
Relative Relief & $\mathrm{R}_{\mathrm{hp}}$ & - & 0.0008 \\
Ruggedness Number & $\mathrm{R}_{\mathrm{N}}$ & - & 0.109 \\
Basin Slope & $\mathrm{S}$ & - & 0.19 \\
\hline
\end{tabular}

The highest and lowest elevations of Ofu River basin are extracted from the DEM (Fig. 7) were 436 and $11 \mathrm{~m}$ above mean sea level ( $m$ asl.), respectively. The Basin relief $(\mathrm{H})$, Relief ratio $\left(R_{h}\right)$ and Relative relief $\left(R_{h p}\right)$ are 425 m, 0.0042 and 0.0008 , respectively while the Ruggedness number and Basin slope are respectively 0.109 and 0.19 . The Relief ratio according to Schumm (1956) is equal to the tangent of the angle formed by two planes intersecting at the mouth of the basin. It is also a measure of the overall steepness of a river basin which is an indicator of the intensity of erosion process operating on the slope of the basin.

The $R_{h}$ value of 0.0042 obtained for Ofu River basin reveals that the basin is morphometrically less susceptible to severe erosion. From the reconnaissance survey conducted, it was observed that the catchment is not affected by serious erosion characteristic of a major part of Kogi East Senatorial district. The relief ratio $\left(\mathrm{R}_{\mathrm{hp}}\right)$ is an important morphometric variable used for the overall assessment of morphological characteristics of terrain.

\section{CONCLUSION}

A quantitative morphometric analysis using remotely sensed data and GIS has been demonstrated to be a fast, convenient and effective method of studying the characteristics of a river basin. Ofu River catchment has a dendritic drainage pattern showing a $3{ }^{\text {rd }}$ order stream network and a total of 39 streams. The high values of bifurcation ratio reveal that a lower and extended peak flow would result from the basin which will reduce the risk of flooding. The low drainage density indicates that the basin has highly permeable sub-soil and thick vegetative cover. This is further buttressed by the low circularity ratio, elongation ratio and form factor. As the basin is elongated in shape, it has a low discharge rate and highly permeable sub soil conditions. The low values of stream frequency and drainage intensity further confirm that the surface runoff is not quickly removed from the basin.

Morphometrically, the basin is well capable of absorbing water into the soil and recharging groundwater while reducing the risk of flooding and possibly increasing the risk of ground water flooding as it is in some parts of the catchment. If such flood will emerge, it could be managed easily from this type of elongated basins than from circular basins by adopting suitable precautionary measures. Although the studied Ofu river basin is not morphometrically susceptible to flood, sustainable management plans should be made in advance to cope with the potential floods that can occur due to high rainfalls.

\section{REFERENCES}

Agarwal, C. S. (1998). Study of drainage pattern through aerial data in Naugarh area of Varanasi district, UP. Journal of the Indian Society of Remote Sensing, 26(4), 169175.

Chorley, R. J.; D. E. Malm, and H. A. Pogorzelski. (1957). A new standard for estimating drainage basin shape. American Journal of Science, 255(2), 138-141.

Faniran, A. (1968). The index of drainage intensity-A provisional new drainage factor. Australian Journal of Science, 31: 328-330.

Garde, R.J. (2006). River Morphology, New Age International (Pvt) Ltd. Publishers, New Delhi.

Gideon, Y. B.; F. B. Fatoye, and J. I. Omada. (2013). Quality Assessment of Physico-Chemical Characteristics of 
Okura River, Kogi State, Nigeria. International Journal of Science and Technology, 2(12): 891-899.

Horton, R. E. (1932). Drainage-basin characteristics. Eos, Transactions American Geophysical Union, 13(1): 350361.

Horton, R. E. (1945). Erosional development of streams and their drainage basins; hydrophysical approach to quantitative morphology. Geological society of America bulletin, 56(3): 275-370.

http://www.nationsonline.org/oneworld/map/nigeriaadministrative-map.htm

Ibrampurkar, M. M. (2012). Hydrological and hydrogeological evaluation of Mhadei River watershed-in Goa and Karnataka (Doctoral dissertation, Goa University).

Imasuen, O.; A. Omali, and I. Ibrahim. (2011). Assessment of environmental impacts and remedies for gully erosion in Ankpa Metropolis and environs, Kogi State, Nigeria. Adv. Applied Sci. Res, 2: 372-384.

Kirpich, Z. P. (1940). Time of concentration of small agricultural watersheds. Civil Engineering, 10(6): 362.

Kulkarni, M. D. (2015). The Basic Concept to Study Morphometric Analysis of River Drainage Basin: A Review. International Journal of Science and Research, 4(7): 22772280 .

Langbein, W. B., and Leopold, L. B. (1964). Quasiequilibrium states in channel morphology. American Journal of Science, 262(6): 782-794.

Le Roux, J. P. (1992). Determining the channel sinuosity of ancient fluvial systems from paleocurrent data. Journal of Sedimentary Research, 62(2): 283-29

Library of Congress (n.d). Administrative Map of Nigeria. Available at https://www.loc.gov/item/2010592721/. Accessed 08/06/2017)

Martins, A. K., and Gadiga, B. L. (2015). Hydrological and Morphometric Analysis of Upper Yedzaram Catchment of Mubi in Adamawa State, Nigeria. Using Geographic Information System (GIS). World Environment, 5(2): 63-69.

Melton, M. A. (1957). An analysis of the relations among elements of climate, surface properties, and geomorphology (No. CU-TR-11). Columbia Univ New York.

Miller, V. C. (1953). A quantitative geomorphic study of drainage basin characteristics in the clinch mountain area Virginia and Tennessee (No. CU-TR-3). Columbia University New York.

Mustafa S. and Yusuf M. I. (2012). A Textbook of Hydrology and Water Resources, Revised Edition. Abuja. Topsmerit Page Publishing Company.
Nag, S.K. (1998). Morphometric analysis using remote sensing techniques in the Chaka sub-basin, Purulia district, West Bengal. J. Indian Soc. remote sensing, 26 (1\& 2): 69 76.

Obi Reddy, G. E.; A. K. Maji, and K. S. Gajbhiye. (2002). GIS for morphometric analysis of drainage basins. GIS India, 11(4): 9-14

Patton, P. C., and Baker, V. R. (1976). Morphometry and floods in small drainage basins subject to diverse hydrogeomorphic controls. Water Resources Research, 12(5): 941-952.

Raj, P. N., and Azeez, P. A. (2012). Morphometric analysis of a tropical medium river system: a case from Bharathapuzha River southern India.Open Journal of Modern Hydrology, 2: 91-98.

Sapkale, J. B. (2013). Cross Sectional and Morphological Changes after a Flood in Bhogawati Channel of Kolhapur, Maharashtra. Indian Geographical Quest, 2: 6878.

Schumm, S. A. (1956). Evolution of drainage systems and slopes in badlands at Perth Amboy, New Jersey. Geological society of America bulletin, 67(5): 597-646.

Strahler, A. N. (1952). Hypsometric (area-altitude) analysis of erosional topography. Geological Society of America Bulletin, 63(11): 1117-1142.

Strahler, A. N. (1957). Quantitative analysis of watershed geomorphology. Eos, Transactions American Geophysical Union, 38(6): 913-920.

Strahler, A. N. (1964). Quantitative geomorphology of drainage basin and channel networks. Handbook of applied hydrology, Ed. Ven Te Chow, 04: 9 - 76.

Waikar, M. L., and Nilawar, A. P. (2014). Morphometric analysis of a drainage basin using geographical information system: a case study. Int $\mathbf{J}$ Multidiscip Curr Res, 2: 179-184.

Withanage, N. S.; N. D. K. Dayawansa, and R. P. De Silva. (2014). Morphometric analysis of the Gal Oya River basin using spatial data derived from GIS. Tropical Agricultural Research, 26(1): 175-188.

Zaidi, F. K. (2011). Drainage basin morphometry for identifying zones for artificial recharge: A case study from the Gagas River Basin, India. Journal of the Geological Society of India, 77(2): 160-166.

Zernitz, E. R. (1932). Drainage patterns and their significance. The Journal of Geology, 498-521. 